\title{
Evaluation of hydromechanical behavior and macro-structure of an expansive soil in the city of Paulista-PE Brazil
}

\author{
Felipe Araújo Silva Barbosa ${ }^{1 *}$, Arthur Gomes Dantas de Araújo ${ }^{2}$, Thalita Cristina Rodrigues Silva ${ }^{1}$, Izabela Medeiros de \\ Lima Bezerra ${ }^{1}$, Antonio Celso Dantas Antonino ${ }^{1}$, and Silvio Romero de Melo Ferreira ${ }^{\text {*** }}$
}

${ }^{1}$ Federal University of Pernambuco (UFPE), Brazil.

${ }^{2}$ Federal Rural University of the Semi-Arid (UFERSA), Brazil.

\begin{abstract}
The characterization of the structural arrangement of an unsaturated soil is important for the understanding of its behavior. For expansive soils, obtaining this information and combining it with an understanding of their intrinsic and extrinsic properties, makes it possible to predict their performance. The experimental procedure for this study was developed using the expansive soil of the Maria Farinha formation in the city of Paulista, in Pernambuco, Brazil. Physical and chemical characterization tests, edometric tests with wetting, and structural analysis through X-Ray computed tomography were performed for both undisturbed and compacted samples, before and after wetting and swelling. The compaction process was performed without any prior air drying and without loosening, beginning with the field moisture level. Based on its liquid limit and plasticity index, the soil can be classified as $\mathrm{CH}$ according to the USCS, moderately acidic, with a swelling potential ranging from high to very high, depending on the initial suction of the sample. The analysis of the soil macro-structure revealed a smaller number of voids in the compacted samples. In addition, it was found that the wetting process caused a reduction of the soil macro pores, in both cases.
\end{abstract}

\section{Introduction}

The growing development of contemporary society has brought with it ever greater geotechnical challenges, making testing methodologies consecrated in the past no longer sufficient to provide support for current decisionmaking, which must deal with new problems. Current knowledge about the structural arrangement and hydromechanical properties of unsaturated soils are seen as essential for understanding and predicting their behavior. In this context, expansive soils stand out because they vary volumetrically due to cyclical changes in moisture/suction, and are under practically constant tensions.

Vilar \& Ferreira (2015) [1] define expansive soils as unsaturated soils consisting of 2:1-type laminar clay minerals, such as montmorillonites and vermiculites. Their presence can be associated with places where evapotranspiration exceeds precipitation, such as arid and semi-arid regions with a tropical or temperate climate, as is the case in northeastern Brazilian (where this study took place).

Construction problems associated with the presence of expansive soils are described by Morais (2017) [2], who reports: cracks in slabs, walls, and foundations of small buildings; cracks in pavement; and even ruptures in pipes and canals.

This situation is aggravated due to the difficulty in recognizing this type of soil through field surveys, such as SPT, and geotechnical characterization tests. Faced with this difficulty, several authors have proposed methodologies to determine the susceptibility and swelling potential of a soil, developing direct methods (laboratory tests with wetting) and indirect methods (those that correlate results of characterization tests and physical indices to indicate swelling potential).

With regard to analysis of the structural arrangement of the soil, there is an increase in the use of techniques that allow not only quantitative, but also qualitative and visual analysis, as is the case with X-Ray Computed Microtomography. This type of test makes it possible to evaluate the variation and arrangement of the soil macropores in a fast, three-dimensional, non-destructive, and detailed way, helping to understand the soil's ability to conduct or retain water, among other factors.

Cavalcante et al. (2015) [3] describe the importance of tomography for understanding flow in porous media (soil), and also highlight the Cellular Automata method as a numerical methodology applicable to these cases.

The experimental procedure for this study was developed using the expansive soil of the Maria Farinha formation, through physical and chemical characterization tests as well as swelling pressure tests with constant volume. In the analysis of the soil structure by X-ray computed tomography, both undisturbed and compacted samples were used, and were tested before and after the wetting and swelling processes.

\footnotetext{
*Felipe Barbosa: felipebarbosa@hotmail.com

** Silvio Ferreira: sr.mf@hotmail.com
} 


\section{Materials and Methods}

The expansive soil used in this study comes from the Maria Farinha formation, which is located in the city of Paulista, in the state of Pernambuco, Brazil (Fig. 01).

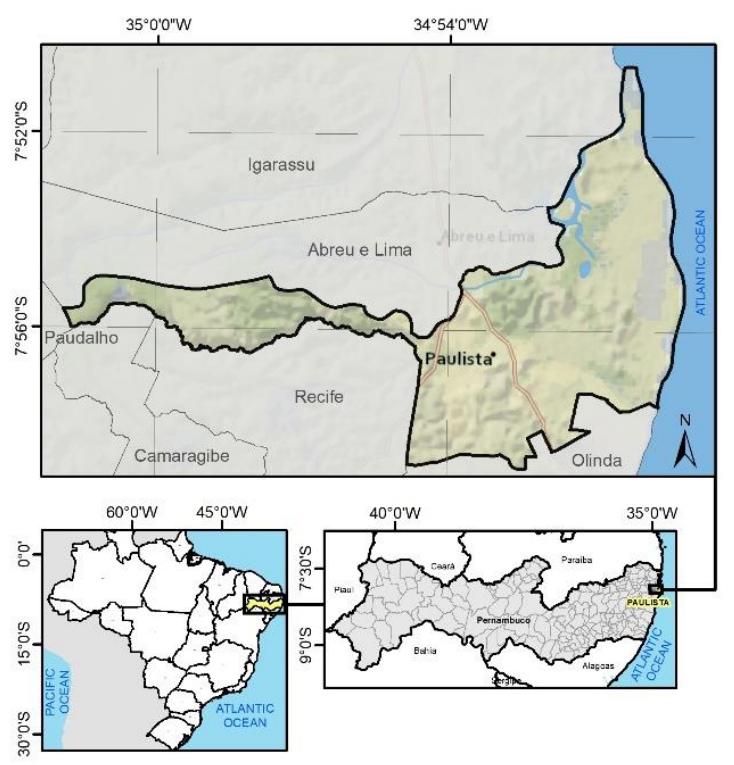

Fig. 1. Map of the municipality of Paulista (Pernambuco, Brazil)

Studies on the soil properties of this locality began with Costa Nunes et al. (1982) [4]. Other studies (Jucá et al. 1992 [5], Paiva 2016 [6], and Morais 2017 [2]) reveal that this soil is predominantly clayey, classified as $\mathrm{CH}$ (USCS). Analyses of the mineralogy of this soil by Paiva (2016) [6], have revealed the presence of mica, kaolinite, and expansive clay minerals (smectite and vermiculite).

For this study, new undisturbed and disturbed samples were collected.

\subsection{Physical and Chemical Characterization Tests}

The physical characterization of the soil was carried out according to the guidelines in the Brazilian standards, with the Atterberg limits tests and compaction performed with and without prior drying and loosening, and the grain size analysis performed with and without the use of deflocculant. This was in order to verify the influence of these processes on the behavior of the soil, because the drying procedure causes disturbances in the soil structure of an expansive soil.

The chemical characterization and classification of the soil was carried out following the guidelines of the Brazilian Agricultural Research Corporation EMBRAPA ([7] and [8]).

\subsection{Swelling Pressure with Constant Volume}

The swelling potential of a soil is directly linked to its moisture and suction when being wetted. In order to evaluate and quantify this variation, four swelling pressure tests with constant volume were performed with different initial moisture and suction values.

This test consists of wetting the soil samples and stabilizing their initial volume by increasing load, making it possible to directly measure the tension necessary to maintain the same initial volume following the wetting. This was done using the same guidelines, equipment, and accessories of a conventional edometric test.

The tested samples were initially molded within metal rings and placed inside vacuum desiccators containing sulfuric acid $\left(\mathrm{H}_{2} \mathrm{SO}_{4}\right)$ solutions, and remained there until their moisture equalized for the scution imposed (Table 1).

Table 1. Concentration of $\mathrm{H}_{2} \mathrm{SO}_{4}$ solution and suction

\begin{tabular}{c|cccc}
\hline $\begin{array}{c}\text { Concentration of } \\
\text { solutions }(\mathrm{g} / \mathrm{ml})\end{array}$ & 1.070 & 1.145 & 1.195 & 1.305 \\
\hline Suction $(\mathrm{MPa})$ & 8.11 & 19.91 & 30.16 & 81.07 \\
\hline
\end{tabular}

Moisture stabilization control for the samples was done through the verification of the stability of their weight. The filter paper and porous stones used in the tests also went through an equalization process at the desired suction, and these items were inserted into the respective desiccators 48 hours before the tests were carried out.

\subsection{Analysis of Soil Macrostructure by Computed Tomography}

The use of computed tomography to study soil structure makes it possible to assess the soil's original macrostructure at different moisture levels, and to better visualize its morphology and macro porosity. (Barbosa, 2019 [9]).

This technique consists of radiography (X-ray incidence) of the sample. During the test procedure, the sample is rotated and the absorption radiographs at each angle are projected onto a screen. The captured images are stored on a computer for reconstruction of the scanned volume and analysis (Fig. 02).

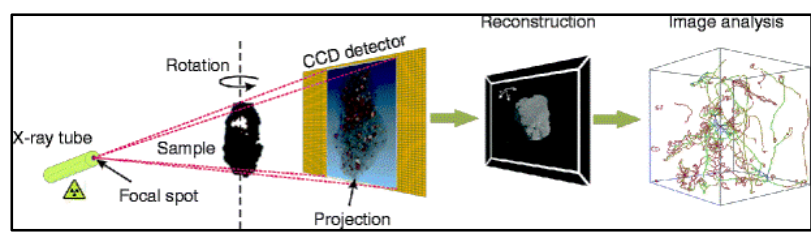

Fig. 2. Tomograph scanner operating system and image reconstruction (Perth et al., 2010 [10]).

The tomography tests performed in this study were done using a third-generation X-ray micro-tomograph, model NIXON XT H 225 ST (Fig 03-a). The parameters used in the image acquisition process were: a a voltage of $160 \mathrm{kV}$, current of $180 \mu \mathrm{A}$, and a copper filter of $0.5 \mathrm{~mm}$ thickness.

The soil samples to be tested were molded in a PVC tube with a diameter and height of $75 \mathrm{~mm}$, fixed to a metallic base. Scanning began after placing the sample within the scanner, with all parameters previously configured (Fig 03-b). 


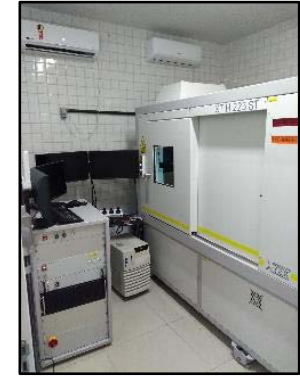

(a)

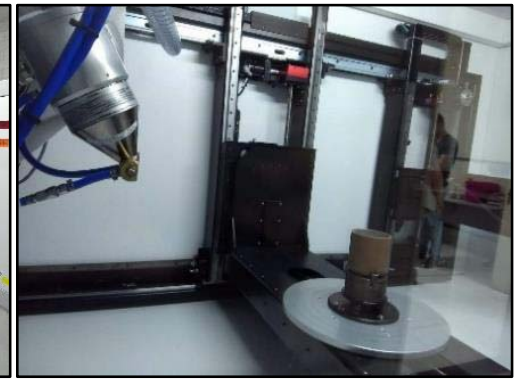

(b)
Fig. 3. Equipment used and test procedure.

Each specimen was scanned twice. The first time, the analysis was carried out in the soil's initial state, in order to verify the natural field conditions or compacted at the optimum moisture level and maximum dry density. The second analysis took place after wetting the soil for 48 hours. During this stage, a dial gauge with a sensitivity of $0.01 \mathrm{~mm}$ was used to verify the stabilization of the soil's expansion over time. This comparison made it possible to evaluate the effects of the soil's swelling on its macrostructure.

The volume of soil analyzed corresponds to the central part of the sample. This was done to circumvent eventual problems related to the disturbing of the sample by the preparation and molding process, as well as to avoid interference due to the change of material from the plastic cast to the soil. The images generated by the tomography were analyzed according to the methodology described by Costa (2016) [11], in which free software ImageJ was used.

\section{Results and Analysis}

\subsection{Physical Characterization}

The results of the grain size analysis, with and without deflocculant, are shown in Fig. 4 and Table 2. In the test using the deflocculant, a high presence of fine particles (clay and silt) was noted. When not used, the sand fraction grows, indicating that the soil particles in their natural state are flocculated.

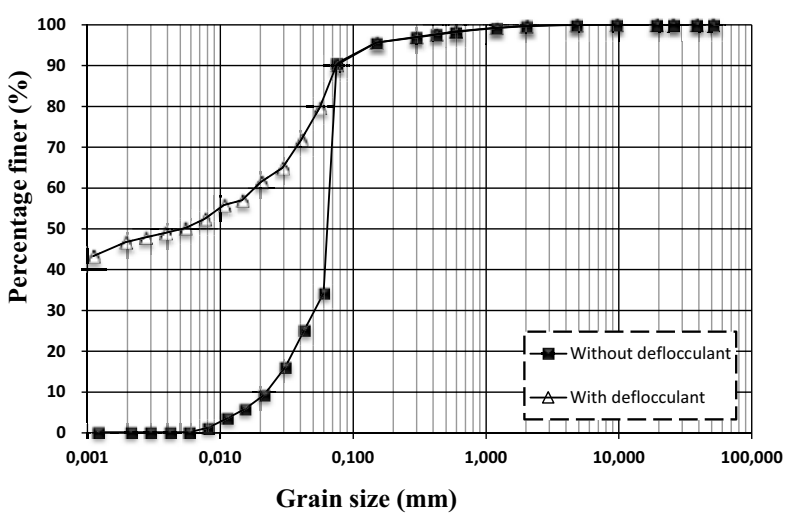

Fig. 4. Grain size curves, with and without deflocculant.
Table 2. Soil size composition and specific gravity.

\begin{tabular}{c|cc}
\hline \multirow{2}{*}{ Soil } & \multicolumn{2}{|c}{ Soil size composition (\%) } \\
\cline { 2 - 3 } & $\begin{array}{c}\text { With } \\
\text { deflocculant }\end{array}$ & $\begin{array}{c}\text { Without } \\
\text { deflocculant }\end{array}$ \\
\hline Clay & 47 & - \\
Silt & 36 & 33 \\
Fine sand & 13 & 63 \\
Medium sand & 3 & 3 \\
Coarse sand & 1 & 1 \\
Gravel & - & - \\
\hline
\end{tabular}

The results of the tests with and without prior preparation revealed a high variation between the Atterberg limit values and for the plasticity index (Table 3).

Table 3. Atterberg limit results.

\begin{tabular}{c|cccccc}
\hline Sample & $\begin{array}{c}\text { LL } \\
(\%)\end{array}$ & $\begin{array}{c}\text { PL } \\
(\%)\end{array}$ & $\begin{array}{c}\text { IP } \\
(\%)\end{array}$ & $\begin{array}{c}\text { SL } \\
(\%)\end{array}$ & $\begin{array}{c}\% \\
\text { clay }\end{array}$ & A \\
\hline $\begin{array}{c}\text { With prior } \\
\text { preparation }\end{array}$ & 62 & 30 & 32 & 16 & 47 & 0.68 \\
\hline $\begin{array}{c}\text { Without prior } \\
\text { preparation }\end{array}$ & 74 & 26 & 48 & 15 & 47 & 1.02 \\
\hline
\end{tabular}

This difference in behavior can be explained due to the formation of lumps during the previous drying of the samples. These lumps make it difficult for water to penetrate and homogenize the sample when tested, leaving the soil with an equivalent grain size different from that of clay.

Analysis of the swelling potential of the soil, considering the Skempton (1953) [12], Williams (1957) [13], and Daksanamurthy and Raman (1973) [14] methods, found that the sample without prior preparation had a very high swelling potential, while the sample with prior preparation had a high swelling potential. According to the Seed et al. (1962) [15] method, both samples showed high swelling potential.

The compaction curves, with and without prior preparation (drying and loosening), are shown in Figure 6 and Table 4. It was noted that the soil without prior preparation had a lower maximum dry density and a higher optimum moisture content than the test with prior preparation. The compaction energy used was Proctor normal.

Formation of lumps during the drying process caused the soil to behave as if it had an equivalent grain size different from the real one.

Table 4. Compaction results.

\begin{tabular}{c|cc}
\hline Sample & $\begin{array}{c}\text { Maximum dry } \\
\text { density }\left(\mathrm{kN} / \mathrm{m}^{3}\right)\end{array}$ & $\begin{array}{c}\text { Optimum } \\
\text { water content } \\
(\%)\end{array}$ \\
\hline $\begin{array}{c}\text { With preparation } \\
\begin{array}{c}\text { Without } \\
\text { preparation }\end{array}\end{array}$ & 14.90 & 23.0 \\
\hline
\end{tabular}




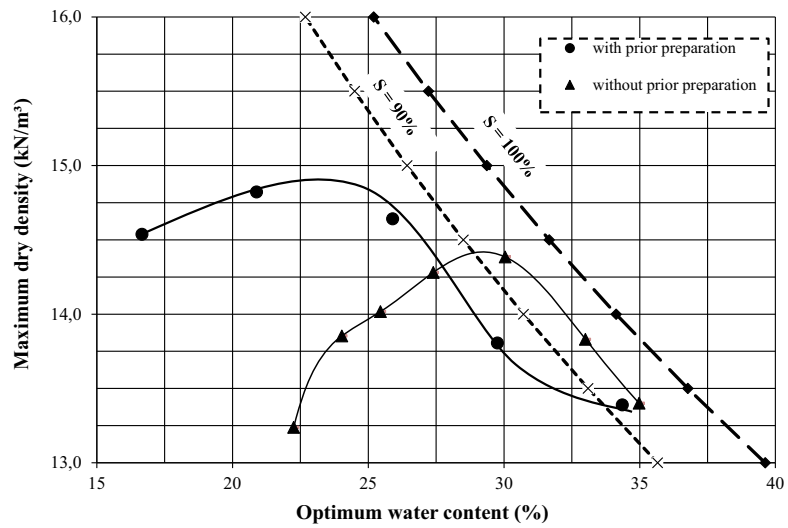

Fig. 6. Compaction curves.

\subsection{Chemical Characterization}

The soil was classified as moderately acidic (based on its $\mathrm{pH}$ in water) and dystrophic (poorly fertile), as it had a base saturation value $(\mathrm{V})$ below $50 \%$. It also had a low organic matter content $(<1 \%)$ and a tendency to expand because its CTC was considered high $(>27 \mathrm{cmolc} / \mathrm{kg}$ ). Table 5 presents the chemical results obtained.

Table 5. Chemical characterization results.

\begin{tabular}{|c|c|c|}
\hline Items & Unit & Results \\
\hline $\mathrm{pH}$ in water & - & 5.48 \\
\hline Organic matter & $\mathrm{g} / \mathrm{kg}$ & 0.76 \\
\hline Aluminum $\left(\mathrm{Al}^{3+}\right)$ & $\mathrm{cmolc} / \mathrm{kg}$ & 21.20 \\
\hline Calcium $\left(\mathrm{Ca}^{2+}\right)$ & $\mathrm{cmolc} / \mathrm{kg}$ & 2.50 \\
\hline Magnesium $\left(\mathrm{Mg}^{2+}\right)$ & $\mathrm{cmolc} / \mathrm{kg}$ & 13.75 \\
\hline Sodium $\left(\mathrm{Na}^{+}\right)$ & $\mathrm{cmolc} / \mathrm{kg}$ & 1.30 \\
\hline Potassium $\left(\mathrm{K}^{+}\right)$ & cmolc/kg & 0.20 \\
\hline $\begin{array}{l}\% \text { Sodium saturation } \\
\text { (n) }\end{array}$ & $\%$ & 3.17 \\
\hline Sum of cations (S) & $\mathrm{cmolc} / \mathrm{kg}$ & 17.72 \\
\hline Hydrogen $\left(\mathrm{H}^{+}\right)$ & $\mathrm{cmolc} / \mathrm{kg}$ & 2.00 \\
\hline $\begin{array}{l}\text { Cation exchange } \\
\text { capacity (T ou CTC) }\end{array}$ & $\mathrm{cmolc} / \mathrm{kg}$ & 40.92 \\
\hline$\%$ Base saturation $(\mathrm{V})$ & $\%$ & 43.30 \\
\hline $\begin{array}{l}\% \text { Aluminum saturation } \\
(\mathrm{m})\end{array}$ & $\%$ & 0.54 \\
\hline $\begin{array}{l}\mathrm{V}=100 \times \mathrm{S} / \mathrm{T} ; \mathrm{m}=100 \times \mathrm{A} \\
\mathrm{S}=\mathrm{Na}^{+}+\mathrm{K}^{+}+\mathrm{Ca}^{2+}+\mathrm{Mg}\end{array}$ & $\begin{array}{l}\mathrm{S}+\mathrm{Al}^{3+} \\
\Gamma \mathrm{C}=\mathrm{S}+\mathrm{A}\end{array}$ & $\mathrm{a}^{+} / \mathrm{T}$ \\
\hline
\end{tabular}

\subsection{Swelling Pressure with Constant Volume}

The swelling pressure values obtained by the constant volume method are shown in Table 6 . It can be seen that the samples submitted to a higher suction, and consequently a lower initial moisture, had a higher swelling pressure. This fact was also observed by Silva (2019) [16] in soil samples from Bonito-PE, Brazil.

According to the Vijayvergiya and Ghazzaly (1973) [17] method, the degree of swelling of the soil varied between high and very high. These results showed the influence of moisture on the swelling potential of expansive soils.
Table 6. Results of the swelling pressure by constant volume method.

\begin{tabular}{|c|c|c|c|c|}
\hline Suction (MPa) & 8.11 & 19.91 & 33.16 & 81.07 \\
\hline $\begin{array}{l}\text { Initial moisture content } \\
(\%)\end{array}$ & 16.0 & 12.5 & 9.0 & 7.7 \\
\hline $\begin{array}{l}\text { Swelling pressure with } \\
\text { constant volume }(\mathrm{kPa})\end{array}$ & 168 & 250 & 438 & 488 \\
\hline $\begin{array}{l}\text { Classification by } \\
\text { Vijayvergiya and } \\
\text { Ghazzaly (1973) [16]. }\end{array}$ & High & High & $\begin{array}{l}\text { Very } \\
\text { high }\end{array}$ & $\begin{array}{l}\text { Very } \\
\text { high }\end{array}$ \\
\hline
\end{tabular}

\subsection{Macro-structural Soil Analysis}

Through analysis of the binary images (in which the soil is shown in black and the voids or macro-pores in white), it is possible to visualize changes in the configuration of the soil macrostructure due to the compaction process. While the natural samples have a higher interconnection between voids, the compacted samples show more isolated voids in lower quantity. There is also a decrease in the number of macro-pores in the samples after the wetting process, for both cases.

Costa (2016) [11] reports that the macro-porosity values found through tomography for smaller grain sizes (clays and silts) diverge from the values obtained through other methods.

This is due to limitations in the resolution of the imagery equipment, as it is not possible to observe volumes smaller than $12.5 \times 10^{-5} \mathrm{~mm}^{3}$, giving an image resolution of $50 \mu \mathrm{m}$. Therefore, the analyses performed by tomography should only be done for macro-porosity of the soil, and not for total porosity.

\subsubsection{Undisturbed Sample}

The binary images of the natural sample are shown in Fig. 6 , in which figure (a) represent the initial state of the sample and figure (b) represent the sample after the process of wetting and swelling. In its initial state, the sample had a moisture level of $25 \%$ and macro-porosity of $4.69 \%$. After wetting, its macro-porosity was $4.48 \%$.

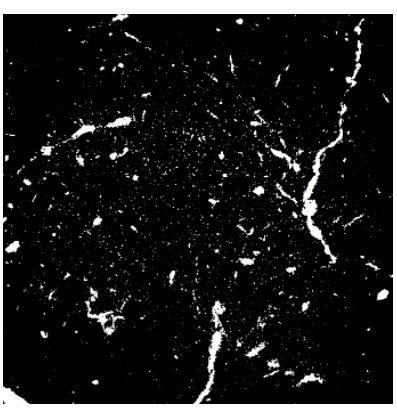

(a)

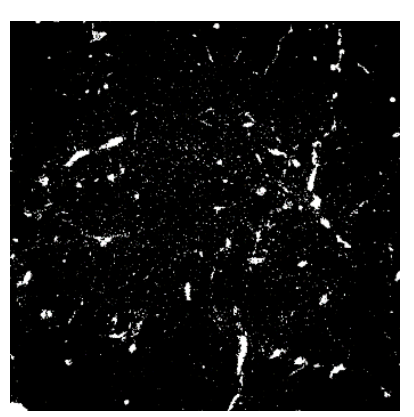

(b)
Fig. 6. Scanning comparison- binarized images of undisturbed sample. 


\subsubsection{Compacted Sample}

The binary images of the compacted sample are shown in Fig. 7, in which figure (a) represent the initial state of the sample and figure (b) represent the sample after the process of wetting and swelling. In its initial state, the sample (compacted at optimum moisture content, maximum dry density, and without prior preparation) had a macro-porosity of $3.82 \%$. After wetting, its macroporosity was $3.30 \%$.

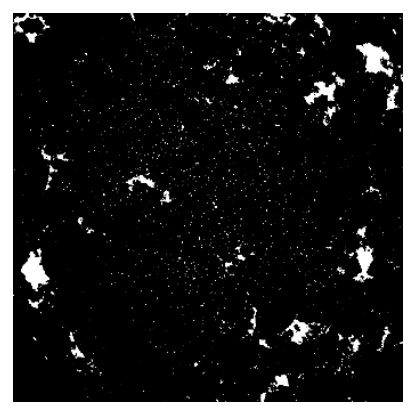

(a)

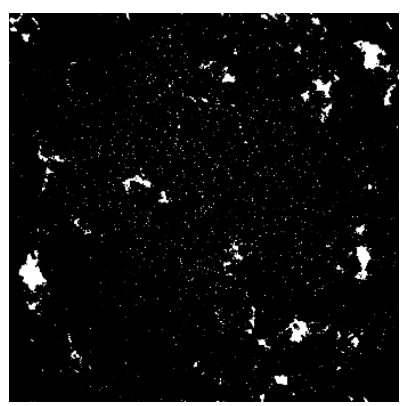

(b)
Fig. 7. Scanning comparison - binarized images of compacted sample.

\section{Conclusions}

The expansive soil from the Maria Farinha formation is formed mainly by fine particles (clay and silt), and is classified as CH (USCS). The swelling potential varied from high to very high, depending on the methods adopted.

Tests carried out with and without prior preparation revealed a change in behavior. The chemical determinations obtained showed that the soil is dystrophic and moderately acidic.

The tomography results compared, both quantitatively and qualitatively, the influence of compaction and wetting on the macro-porosity of the soil. The compacted sample had more isolated voids of lower quantity, when compared to the natural sample. In both cases, there was a reduction in macro-pores due to the wetting and swelling process.

\section{Acknowledgment}

The authors would like to thank UFPE, especially the Graduate Program in Civil Engineering and the Department of Nuclear Energy, for the academic incentive and support structure for this study, as well as the companies COMPESA and BRK Environmental for their logistical support during the sample collection.

\section{References}

1. O. M. Vilar \& S. R. M. Ferreira (2015). Solos Colapsíveis e Expansivos. In: Solos não saturados no contexto geotécnico, ed $1^{\text {st }}$, p. 416-440 (Cap. 15).
2. J. J. O. Morais (2017). Caracterização Geotécnica da Expansividade de um Solo Argiloso do Município de Paulista/PE (Federal University of Pernambuco UFPE, Brazil).

3. A. L. B. Cavalcante; L. P. F. Borges; J. C. Carvalho. (2015). Tomografias computadorizadas e análises numéricas aplicadas à caracterização da estrutura porosa de solos não saturados. In: Solos não saturados no contexto geotécnico, ed $1^{\text {st }}$, p. 531-553 (Cap. 19).

4. A. J. Costa Nunes; E. M. Vasconcelos; R. L. M. Pandolfi. (1982). Ocorrência de propriedades de Engenharia de Solos Expansivos na Área do Grande Recife. In: $7^{\circ}$ C.B.M.S.E.F.- vol. 5, p.193-209, Recife.

5. J. F. T. Jucá; J. A. Gusmão Filho; J. M. Justino da Silva. (1992). Laboratory and field tests on an expansive soil in Brazil. In: $7^{\circ}$ International Conference on Expansive Soils, p. 337-342, Dallas

6. S. C. Paiva. (2016). Estudo do comportamento geomecânico dos solos expansivos dos municípios de Cabrobó, Paulista e Ipojuca/PE e de suas misturas com cal (Federal University of Pernambuco - UFPE, Brazil).

7. Empresa Brasileira de Pesquisa Agropecuária EMBRAPA (2001). In: Manual de métodos de análise de solo, ed. $2^{\text {nd }}$.

8. Empresa Brasileira de Pesquisa Agropecuária EMBRAPA (1999). In: Sistema Brasileiro de Classificação de Solos, ed. $1^{\text {st }}$.

9. F. A. S. Barbosa. (2019). Análise do comportamento hidromecânico e da dinâmica de fissuração de um solo expansivo (Federal University of Pernambuco UFPE, Brazil).

10. S. Peth; J. Nellesen; G. Fischer; R. Horn. (2010). Dynamics of soil por espace structure investigated by X-ray microtomography. In: $19^{\text {th }}$ World Congress on Soil Science, Soil Solutions for a Changing World, Brisbane.

11. L. F. Costa. (2016). Tomografia computadorizada de raios-X aplicada à caracterização do espaço poroso do solo (Federal University of Pernambuco - UFPE, Brazil).

12. A. W. Skempton. (1953). The colloidal activity of clays. In: $3^{\text {rd }}$ International Conference on Soil Mechanics and Foundations, p. 57-61, Zurich.

13. A. A. B. Williams. (1957). Studies of shear strength and bearing capacity of some partially saturated sands. In: $4^{a}$ Conference on soil Mechanics and Foundation Engineering, London.

14. V. Daksanamurty \& V. A. Raman. (1973). A simple method of identifying an expansive soil. In: Soils and Foundation, vol 13, n. 1, p. 97-104.

15. H. B. Seed; R. J. Woodward; R. Lundgren. (1962). Prediction of swelling potencial for compacted clays. In: Journal Soil Mechanics and Foundations Division, vol 88, p. 53-87. 
16. T. C. R. Silva (2019). Avaliação do comportamento hidrômecanico e do processo de propagação de fissuras de solo expansivo do município de Bonito/PE (Federal University of Pernambuco UFPE, Brazil).

17. V. N. Vijayvergiya \& O. I. Ghazzaly. (1973). Predicton of swelling potencial for natural clays. In: $3^{\circ}$ International Conference on Expansive Solis, p. 227-236, Hayfa. 